\title{
PERBANDINGAN PENGAKUAN PENDAPATAN JASA KONSTRUKSI ANTARA METODE KONTRAK SELESAI DAN PERSENTASE PENYELESAIAN PADA CV. RAFFI JAYA PERKASA KABUPATEN MUSI BANYUASIN
}

\author{
Oleh \\ Masri Ermawijaya \\ Program Studi S1 Akuntansi STIE Rahmniyah Sekayu \\ (masriermawijaya60@gmail.com)
}

\begin{abstract}
Abstrak
Tujuan dari penelitian ini adalah untuk mengetahui perbandingan pengakuan pendapatan jasa onstruksi antara metode kontrak selesai dan metode persentase penyelesaian atas pengerjakaan proyek peningkatan jalan dari Desa Sumber Agung menuju Kelurahan Keluang dengan beton kecamatan Keluang yang dikerjakan oleh CV. Raffi Jaya Perkasa Tahun 2019. Teknik analisis yang digunakan adalah kuantitatif dan kualitatif, dan data yang digunakan adalah data sekunder yaitu data biaya proyek yang dikerjakan oleh CV.Raffi Jaya Perkasa, sedangkan teknik pengumpulan data dengan cara dokumentasi dan wawancara. Hasil pembahasan diperoleh bahawa CV. Raffi Jaya Perkasa dalam menghitung biaya jasa konstruksi menggunakan metode kontrak selesai, akibatnya perusahaan tidak dapat mengakui pendapatan dan laba sampai kontrak selesai dan perusahaan akan menunda kewajiban pajak untuk periode mendatang sampai kontrak selesai. Sesuai Standar Akuntansi Keuangan Entitas Tanpa Akuntabilitas Publik (SAK ETAP) bahwa perusahaan konstruksi hanya diperkenankan menggunakan metode persentase penyelesaian dalam menghitung pendapatan dan beban jasa konstruksi, hal ini dilakukan agar pendapatan dan biaya dapat diakui sesuai dengan progress penyelesaian proyek dan tidak menangguhkan pengakuan unsur-unsur ini sampai kontrak diselesaikan. Jumlah Pendapatan akan diakui didasarkan pada kemajuan penyelesaian proyek, sehingga laba yang dihasilkan lebih wajar dan dapat di hitung secara akurat setiap akhir periode.
\end{abstract}

Kata kunci: Perbandingan, Pengakuan, Pendapatan Jasa Kontruksi, Metode kontrak selesai, Metode persentase penyelesaian

\section{PENDAHULUAN}

\section{Latar Belakang Masalah}

Setiap usaha yang dijalankan pasti mempunyai tujuan yang ingin dicapai, tujuan yang ingin dicapai adalah mencari laba yang maksimal. Jenis usaha yang dapat dijalankan, antara lain usaha dibidang jasa konstruksi yang melakukan pekerjaan sesuai dengan petunjuk yang disepakati antara pemberi kerja dan 
pelaksana kerja yang diikat dengan kontrak perjanjian kerjasama kedua belah pihak.

Akuntansi telah mengatur untuk pengakuan laba pada perusahaan konstruksi ini. Metode yang dianjurkan oleh SAK ETAP Bab 20 untuk perusahaan yang bergerak di bidang kontruksi adalah metode persentase penyelesaian kontrak dan metode kontrak selesai. Metode kontrak selesai ini digunakan oleh perusahaan konstruksi yang melaksanakan proyek dengan masa pengerjaannya tidak lebih dari satu tahun atau satu periode akuntansi. Sedangkan metode prosentase penyelesaian digunakan perusahaan konstruksi yang melaksanakan proyek dengan masa pengerjaannya lebih dari satu tahun atau lebih dari satu periode akuntansi, karena metode presentase penyelesaian kontrak yang lebih tepat untuk diterapkan dalam mencatat dan mengakui pendapatan dan beban yang di cerminkan dalam laporan keuangan yaitu laporan laba-rugi menujukkan pendapatan yang wajar, pembayaran dan penerimaan uang belum di realisir.

Laporan keuangan menggambarkan kondisi keuangan dan hasil usaha suatu perusahaan pada saat tertentu dan jangka waktu tertentu. Laporan keuangan harus disajikan dengan wajar dan tepat waktu pada periode akuntansi. Salah satu unsur yang sangat berkaitan dalam menghasilkan besar kecilnya laba perusahaan adalah pendapatan.

Standar akuntansi keuangan entitas tanpa akuntabilitas publik (SAK ETAP, 2016: 20) pendapatan adalah penghasilan yang timbul dalam pelaksanaan aktivitas entitas yang biasa dan dikenal dengan sebutan yang berbeda seperti penjualan, imbalan, bunga, deviden, royalti, dan sewa. Pendapatan hanya meliputi arus masuk bruto dari manfaat ekonomi yang diterima dan dapat diterima oleh entitas itu sendiri.

Permasalahan yang sering terjadi adalah kurang sinkronnya antara teori yang telah diatur dalam SAK ETAP dengan kebijakan yang harus ditempuh oleh pemberi kerja dan pelaksana kerja. Ketidaksinkronan berhubungan dengan pengakuan pendapatan, dimana pada akhir tahun seringkali proyek yang dilaksanakan belum selesai $100 \%$ tetapi ada kesepakatan antara pemberi kerja dengan pelaksana kerja yang dituangkan dalam perjanjian bahwa pelaksana kerja 
akan menyelesaikan pekrjaannya pada awal tahun anggaran yang akan datang. Kebijaksanaan ini diambil untuk mengatasi pembayaran dilakukan paling lambat akhir tahun yang bersangkutan dengan ketentuan pengerjaan proyek sudah selesai $100 \%$. Sedangkan terhambatnya masa penyelesaian pekerjaan proyek dikarenakan selain waktu pelaksanaan tanpa toleransi tambahan waktu akibat terlambatnya waktu tender proyek sehingga waktu pelaksanaan proyek akan terganggu, selain itu hambatan lainnya seperti hujan, banjir, gempa dan hambatan lainnya, sehingga sampai dengan akhir tahun pekerjaan tersebut belum dapat diselesaikan $100 \%$. Sedangkan Pendapatan jasa kontruksi harus dihitung dengan akurat dan harus dipastikan apakah sudah sesuai dengan Standar Akuntansi Keuangan Entitas Tanpa Akuntabilitas Publik (SAK ETAP: 20). Metode pengakuan pendapatan jasa kontruksi yang diakui dalam SAK ETAP adalah metode persentase penyelesaian, metode ini menilai dan mengakui pendapatan laba kotor sesuai dengan kemajuan perusahaan dalam menyelesaikan kontrak.

CV. Raffi Jaya Perkasa adalah salah satu perusahaan yang bergerak di bagian jasa kontruksi dan pengadaan barang yang beralamat di Dusun II No 78 B Desa Muara Teladan Kecamatan Sekayu Sumatera Selatan, mengakui pendapatan dan beban dengan menggunakan metode kontrak selesai untuk semua proyeknya baik itu untuk proyek pendek dan proyek jangka panjang sehingga tidak sinkron dengan ketentuan dalam SAK ETAP.

\section{Rumusan Masalah}

Berdasarkan fenomena yang terjadi, maka permasalahannya dapat dirumuskan sebagai berikut yaitu :

1. Bagaimana Membandingkan Pengakuan Pendapatan Jasa Kontruksi Antara Metode Kontrak Selesai dan Persentase Penyelesaian Pada CV. Raffi Jaya Perkasa?

2. Manakah dari Pengakuan Pendapatan Jasa Kontruksi Antara Metode Kontrak Selesai dan Persentase Penyelesaian Pada CV. Raffi Jaya Perkasa yang menghasilkan laba yang wajar? 


\section{Tujuan Penelitian}

Berdasarkan rumusan permasalahan diatas, maka tujuan penelitan yang diharapkan perusahaan adalah dapat :

1. Membandingkan pengakuan pendapatan jasa kontruksi antara Metode Kontrak Selesai dan Persentase Penyelesaian Pada CV. Raffi Jaya Perkasa?

2. diantara Pengakuan Pendapatan Jasa Kontruksi Antara Metode Kontrak Selesai dan Persentase Penyelesaian Pada CV. Raffi Jaya Perkasa yang dapat menghasilkan laba yang wajar.

\section{LANDASAN TEORI}

\section{Pengertian Pendapatan}

Pendapatan adalah arus masuk bruto dari manfaat ekonomi yang timbul dari aktivitas normal entitas selama satu periode, jika arus masuk tersebut mengakibatkan kenaikan ekuitas yang tidak berasal dari kontribusi penanaman modal. Menurut Dwi Martani dan Sylvia Veronica NPD, dkk (2017:115) "Pendapatan merupakan penghasilan yang berasal dari aktivitas operasi utama perusahaan, misalkan aktiviatas penyediaan jasa bagi perusahaan jasa.

Ikatan akuntansi Indonesia dalam standar akuntansi keuangan entitas tanpa akuntabilitas publik (SAK ETAP, 2016: 20) "pendapatan adalah penghasilan yang timbul dalam pelaksanaan aktivitas entitas yang biasa dan dikenal dengan sebutan yang berbeda seperti penjualan, imbalan, bunga, dividen, royalti dan sewa".

Pendapatan dapat disimpulkan adalah penghasilan yang berasal dari aktivitas operasi utama perusahaan yaitu dari aktivitas entitas biasa.

\section{Pengakuan Pendapatan}

Martani dkk (2016:208) "pendapatan diakui ketika kemungkinan bahwa manfaat ekonomi akan mengalir ke dalam perusahaan dan nilai manfaat tersebut dapat diukur secara andal."

SAK ETAP (paragraf 20.7: 2016) menyatakan bahwa sebagai kriteria pengakuan pendapatan biasanya diterapkan secara terpisah untuk setiap transaksi. Kriteria tersebut dapat diidentifikasi secara terpisah dari suatu transaksi tunggal supaya mencerminkan substansi dari transaksi tersebut, dan sebaliknya jika 
kriteria pengakuan diterapkan pada dua atau lebih transaksi bersama-sama bila keduanya terhubungkan, sehingga efek komersial tidak dapat dipahami tanpa mengacu pada rangkaian transaksi secara keseluruhan.

\section{Pengakuan Pendapatan Kontruksi}

Martani dkk (2017:222) menyatakan bahwa pengakuan pendapatan dan beban kontrak kontruksi dapat dibedakan menjadi 2 (dua) metode yaitu:

1) Metode Persentase Penyelesaian

Perusahaan mengakui pendapatan, beban, dan laba setiap periodenya berdasarkan tahap penyelesaian kontrak, yaitu berdasarkan persentase penyelesaian. Dengan demikian pendapatan, beban, dan laba yang dilaporkan dapat diatribusikan menurut penyelesaian pekerjaan secara proporsional. Metode ini memberi informasi yang berguna mengenai cakupan aktivitas kontrak dan kinerja selama satu periode.

Perusahaan mengakumulasi biaya kontruksi ditambah dengan laba yang diperoleh sampai akhir priode dalam suatu akun yaitu :

a. Pekerjaan dalam proses (construction in process).

b. Mengakumulasi penagihan termin dalam akun kontra yaitu termin (progress billing)

2) Metode biaya terpulihkan

Dalam beberapa kondisi ketika metode persentase penyelesaian tidak dapat digunakan, maka menurut metode ini pendapatan hanya diakui sebesar biaya yang telah terjadi sepanjang biaya tersebut diperkirakan dapat terpulihkan. Ketika semua biaya telah diakui maka laba baru dapat diakui.

SAK-ETAP (paragraf 20.19: 2016) pengakuan pendapatan dapat menggunakan metode persentase penyelesaian, yaitu sebagai berikut:

1. Entitas melakukan penelaahan dan (jika perlu) mengubah estimasi pendapatan dan biaya saat transaksi jasa atau kontrak kontruksi berlangsung.

2. Entitas harus menentukan tingkat penyelesaian dari uatu transaksi atau kontrak dengan menggunakan metode yang dapat mengukur dengan andal sebagian besar pekerjaan yang dilaksanakan. 
3. Entitas harus mengenali biaya yang berhubungan dengan aktivitas masa depan atas transaksi atau kontrak, misalnya bahan baku ataupembayaran diimuka, sebagai suatu aset jika biaya tersebut memiliki kemungkinan besar untuk dipulihkan.

4. Entitas harus secepatnya mengakui sebagai beban atas semua biaya yang tidak mungkin dipulihkan.

5. Jika hasil dari kontrak kontruksi tidak dapat diestimasi secara andal, maka entitas:

a. Harus mengakui pendapatan hanya sebesar nilai kontrak yang memiliki kemungkinan besar untuk dipulihkan.

b. Mengakui biaya kontrak sebgai beban sesuai dengan periode terjadinya.

6. Jika ada kemungkinan bahwa harga perolehan kontrak akan melebihi jumlah pendapatan kontrak dalam kontrak kontruksi, maka ekspektasi kerugian harus segera diakui sebagai beban.

7. Jika kolektabilitas dari suatu jumlah yang telah diakui sebagai pendapatan kontrak tidak mungkin lagi, maka entitas harus mengakui jumlah yang tidak tertagih tersebut sebagai beban bukan melakukan suatu penyesuaian atas jumlah pendapatan kontrak.

Perusahaan menggunakan dasar yang andal dalam mengukur pekerjaan yang dilakukan. Tergantung dari sifat kontraknya, dasar yang dapat digunakan, yaitu:

a. Proporsi biaya kontrak yang terjasi dibandingkan estimasi total biaya kontrak.

b. Hasil survei pekerjaan yang telah dilakukan.

c. Penyelesaian berdasarkan proporsi fisik dari pekerjaan kontrak

Sedangkan menurut Stice dan Skousen (2011:510) Dalam situasi tertentu perusahaan dapat mengunakan metode kontrak selesai (completed-contract method) dimana perusahaan mengakui pendapatan sampai pengerjaan proyek selesai, namun laba rugi mungkin tidak melaporkan dengan berarti pencapaian periodik dari perusahaan untuk jenis kontrak konstruksi jangka panjang, hal ini 
berarti laba rugi baru diakui apabila pengenjaan proyek benar-benar selesai $100 \%$

\section{Kontrak dan Jenis kontrak Kontruksi}

\section{Pengertian Kontrak Kontruksi}

Diana dan Setiawati (2017: 383), memberikan pengertian bahwa Kontrak kontruksi adalah "kesepakatan antara klien (pembeli) dengan kontraktor (sebagai penjual) untuk kontruksi suatu aset atau suatu kombinasi asset", sedangkan jika berdasarkan ketentuan dalam SAK-ETAP (paragraf 20.15: 2016), Jika hasil kontrak kontruksi dapat diestimasi secara andal, maka entitas harus mengakui pendapatan kontrak dan biaya kontrak yang berhubungan dengan kontrak kontruksi masing-masing sebagai pendapatan dan beban yang disesuaikan dengan tingkat penyelesaian aktivitas kontrak pada akhir periode pelaporan (seringkali dimaksudkan sebagai metode persentase penyelesaian). Estimasi hasil yang andal membutuhkan estimasi tingkat penyelesaian, biaya masa depan dan kolektabilitas tagihan yang andal.

\section{Jenis Kontrak Kontruksi}

Menurut Martani dkk (2017: 221) kontrak kontruksi terdiri dari dua jenis, yaitu sebagai berikut:

1) Kontrak harga tetap

kontrak harga tetap adalah kontrak kontruksi dengan syarat bahwa kontraktor telah menyetujui nilai kontrak tetap atau tarif tetap yang ditentukan perunit output.

2) Kontrak biaya plus

kontrak biaya plus adalah kontrak kontruksi dimana kontraktor mendapat penggantian untuk biaya-biaya yang telah diizinkan atau telah ditentukan ditambah imbalan.

\section{METODOLOGI PENELITIAN}

\section{Jenis dan Sumber Data}

Sugiyono (2019: 08) mengatakan bahwa terdapat dua jenis data menurut sumbernya, yaitu: 
1. Data Primer, adalah adalah data yang pertama kali dicatat dan dikumpulkan. Data primer dalam penelitian ini berupa data tentang sejarah perusahaan.

2. Data sekunder, adalah data yang sudah tersedia dan dikumpulkan oleh pihak lain. Data Sekunder berupa dokumen arsip perusahaan, berupa laporan biaya pengerjaan proyek peningkatan jalan dari desa Sumber Agung menuju Kelurahan Keluang dengan beton kecamatan Keluang yang dikerjakan oleh CV. Raffi Jaya Perkasa Tahun Anggaran 2019.

\section{Teknik Pengumpulan Data}

Menurut Sanusi (2012: 105) yaitu:

1. Cara survei

Cara survei merupakan cara pengumpulan data dimana peneliti atau pengumpulan data mengajukan pertanyaan atau pernyataan kepada responden baik dalam bentuk lisan maupun secara tertulis. Cara survei terbagi menjadi dua cara, yaitu:

a. Wawancara

b. Kuesioner

2. Cara observasi

Metode observasi digunakan bila peneliti berkenaan dengan perilaku manusia, proses kerja, gejala-gejala alam dan bila responden yang diamati tidak terlalu besar.

\section{Cara dokumentasi}

Cara dokumentasi biasanya dilakukan untuk mengumpulkan data sekunder dari berbagai sumber, baik secara pribadi maupun kelembagaan. Data seperti: laporan keuangan, rekapitulasi personalia, struktur organisasi, peraturanperaturan, data-data produksi, surat wasiat, riwayat hidup, riwayat perusahaan, dan sebagainya.

Teknik pengumpulan data yang digunakan dalam penelitian ini adalah wawancara dengan memberikan daftar pertanyaan kepada pihak CV. Raffi Jaya Perkasa Kabupaten Musi Banyuasin dan menggunakan cara dokumentasi yaitu kontrak pekerjaan konstruksi fisik CV. Raffi Jaya Perkasa dengan Dinas Pekerjaan Umum dan Penataan Ruang (PUPR) Musi Banyuasin, laporan biaya 
proyek peningkatan jalan dari desa Sumber Agung menuju Kelurahan Keluang dengan beton Kecamatan Keluang yang dikerjakan oleh CV. Raffi Jaya Perkasa Tahun Anggaran 2019.

\section{Teknik Analisis Data}

Sugiyono (2018: 7) menjelaskan terdapat dua cara yang digunakan untuk menganalisis data, yaitu:

\section{Teknik Analisis Kualitatif}

Merupakan analisis yang datanya diperoleh dari berbagai sumber, dengan menggunakan teknik pengumpulan data yang bermacam-macam (trianggulasi), dan dilakukan secara terus menerus sampai datanya jenuh.

\section{Teknik Analisis Kuantitatif}

Adalah analisis data yang digunakan sudah jelas, yaitu diarahkan untuk menjawab rumusan masalah atau menguji hipotesis yang telah dirumuskan dalam penelitian.

Teknik analisis data yang yang digunakan dalam penelitian ini adalah menggunakan teknik analisis kuantitatif dan kuatitatif tentang perbandingan pengakuan pendapatan berdasarkan metode kontrak selesai dan metode persentase penyelesaian jasa konstruksi pada CV. Raffi Jaya Perkasa Kabupaten Musi Banyuasin, dengan cara membandingkan, mmperhitungkan dan menjelaskan serta memberikan penjelasan-penjelasan yang relevan dengan permasalahan yang di hadapi CV. Raffi Jaya Perkasa Kabupaten Musi Banyuasin dalam menghitung biaya proyek yang disesuaikan dengan Standar Akuntansi Keuangan Entitas Tanpa Akuntabilitas Publik (SAK ETAP).

\section{PEMBAHASAN}

Berdasarkan permasalahan diatas, maka pembahasan yang dilakukan yaitu dengan membandingkan perhitungan pendapatan dan biaya kontsruksi atas pengerjaan proyek peningkatan jalan dari desa Sumber Agung menuju Kelurahan Keluang dengan beton Kecamatan Keluang yang dikerjakan oleh CV. Raffi Jaya Perkasa Tahun 2019 dengan menggunakan metode kontrak selesai dan metode 
persentase penyelesaian, menganalisis keduanya serta menjelaskan perbedaan dan hasil yang diperoleh sehingga menghasilkan laba yang wajar.

\section{Pengakuan Pendapatan}

\section{Pengakuan Pendapatan Menggunakan Metode Persentase Penyelesaian}

Pengakuan pendapatan kontruksi menurut SAK ETAP Bab 20 hanya ada satu metode yaitu metode persentase penyelesaian, dimana hasil kontrak dapat di estimasikan secara andal, dan entitas harus mengakui pendapatan dan beban yang sesuai dengan tingkat penyelesaian aktivitas kontrak pada akhir periode pelaporan. Pendapatan dan beban proyek dapat dihitung sebagai berikut:

Tahun 2019 : Tingkat kemajuan phisik selama tahun 2019 adalah 98\%. Dengan demikian pendapatan tahun 2019 adalah 98\% x Nilai kontrak : 98\% x Rp. 1.481.380.000 = Rp. 1.451 .752 .400

Dengan demikian jurnal yang akan dicatat CV Raffi Jaya Perkasa pada tahun 2019 adalah sebagai berikut :

\begin{tabular}{|lrr|}
\hline Dasar perhitungan : & & \\
\hline Jumlah Termin & & 1.451 .752 .400 \\
Potongan uang muka 20\% & 290.350 .480 & \\
PPN 10\% & 131.977 .491 & \\
PPh 1,5\% & $\underline{21.776 .286}$ & \\
Total potongan & & $\underline{444.104 .257}$ \\
Kas yang diterima & & $\mathbf{1 . 0 0 7 . 6 4 8 . 1 4 3}$ \\
\hline \hline
\end{tabular}

\section{Jurnal yang diperlukan :}

1. Saat pencatatan termin proyek

Piutang Proyek 1.451 .752 .400

Proyek selesai 1.451 .752 .400

2. Saat penerimaan pembayaran kas 1.007.648.143

Potongan hutang uang muka 290.350 .480

Potongan PPN 131.977 .491

Potongan PPh 21.776 .286

Piutang proyek 1.451 .752 .400 


\section{Saat serah terima proyek}

Proyek selesai

Proyek dalam proses

$$
1.451 .752 .400
$$

Tahun 2020 : Proyek yang belum selesai 100\% akan diselesaikan pada bulan Januari 2020 sesuai dengan perjanjian yang telah disepakati antara pemberi kerja dan kontraktor. Dengan demikian tingkat kemajuan phisik selama tahun 2020 adalah $2 \%$ x Nilai kontrak : $2 \%$ x Rp. $1.481 .380 .000=$ Rp. 29.627 .600

Dengan demikian jurnal yang akan dicatat CV Raffi Jaya Perkasa pada tahun 2020 adalah sebagai berikut :

\begin{tabular}{|lrr|}
\hline Dasar Perhitungan : & \\
\hline Jumlah termin & 29.627 .600 \\
\hline \hline Potongan uang muka 20\% & 5.925 .520 & \\
PPPN 10\% & 2.693 .418 & \\
PPh 1,5\% & $\underline{444.414}$ & \\
Total potongan & & $\underline{9.063 .352}$ \\
Kas yang diterima & & $\mathbf{2 0 . 5 6 4 . 2 4 8}$ \\
\hline
\end{tabular}

\section{Jurnal yang diperlukan :}

\section{Saat pencatatan termin proyek}

Piutang Proyek 29.627 .600

Proyek selesai

\section{Saat penerimaan pembayaran}

kas 20.564.248

Potongan hutang uang muka

Potongan PPN (10\%)

2.693 .418

Potongan PPh (1.5\%)

Piutang proyek

29.627 .600

3 Saat serah terima proyek

Proyek selesai

29.627 .600

Proyek dalam proses 29.627 .600 


\section{Pengakuan Pendapatan Jasa Konstruksi Menggunakan Metode Kontrak Selesai}

Metode kontrak selesai adalah metode pengakuan pendapatan dimana perusahaan tidak mengakui pendapatan dan keuntungan sampai kontrak selesai. Metode ini biasa terjadi dalam kontrak jangka panjang seperti kontruksi, yang seringkali menghadapi ketidakpastian terkait dengan panggalangan dana. Selanjutnya, perusahaan akan menunda kewajiban pajak untuk periode mendatang sampai kontrak selesai.

Untuk metode kontrak selesai perusahaan mengakui dan mengukur pendapatan pada periode penyelesaian pekerjaan mencapai $100 \%$ dan untuk tahun 2019 perusahaan tidak melakukan pengukuran pendapatan kontrak dan biaya kontrak CV Raffi Jaya Perkasa terkait pekerjaan proyek peningkatan jalan dari desa Sumber Agung menuju Kelurahan Keluang dengan beton kecamatan Keluang sedangkan pada tahun 2019 perusahaan mengakui pendapatan sebesar nilai kontrak sebesar Rp.1.481.380.000,00 karena pemberi kerja dan kontraktor telah sepakat bahwa proyek tersebut telah dianggap selesai 100\% pada tahun 2019 perusahaan melakukan pengukuran sebagai berikut :

\section{Tahun 2019}

Perusahaan telah melakukan pengukuran pendapatan sebagai berikut :

Pendapatan = Harga kontrak $\mathrm{x} 100 \%$

$$
\begin{aligned}
& =\text { Rp. } 1.481 .380 .000,00 \times 100 \% \\
& =\text { Rp. } 1.481 .380 .000,00
\end{aligned}
$$

\section{Tahun 2020}

Pada tahun ini perusahaan tidak lagi mengakui pendapatan karena untuk proyek peningkatan jalan dari desa Sumber Agung menuju Kelurahan Keluang dengan beton kecamatan Keluang telah diakui sepenuhnya di tahun 2019 yang lalu sebesar nilai kontrak yang disepakati yaitu Rp. 1.481.380.000,00, sehingga tahun 2020 tidak ada pengakuan pendapatan. 


\section{Perbandingan Pengakuan Pendapatan Jasa Konstruksi Menggunakan Metode Kontrak Selesai dan Metode Persentase Penyelesaian}

Untuk perhitungan biaya konstruksi yang seharusnya di lakukan oleh perusahaan atas proyek Peningkatan Jalan Desa Sumber Agung menuju Kelurahan Keluang Kecamatan Keluang tahun 2019 berdasarkan metode kontrak selesai dengan metode persentase penyelesaian dapat disajikan dalam tabel berikut ini :

Tabel 1

Perhitungan Biaya Proyek

Peningkatan Jalan Desa Sumber Agung menuju Kelurahan Keluang

Kecamatan Keluang CV Raffi Jaya Perkasa

Tahun Anggaran 2019

\begin{tabular}{|c|c|c|c|c|}
\hline \multirow{3}{*}{ Biaya Proyek } & \multirow{2}{*}{\multicolumn{2}{|c|}{$\begin{array}{c}\text { Metode Persentase Penyelesaian } \\
\text { Tahun Anggaran }\end{array}$}} & \multirow{2}{*}{\multicolumn{2}{|c|}{$\begin{array}{c}\text { Metode Kontrak Selesai } \\
\text { Tahun Anggaran }\end{array}$}} \\
\hline & & & & \\
\hline & 2019 & 2020 & 2019 & 2020 \\
\hline Biaya Bahan & 986.852 .331 & 20.139 .843 & 1.006 .992 .175 & 0 \\
\hline Biaya Tenaga Kerja & 92.100 .876 & 1.879 .610 & 93.980 .485 & 0 \\
\hline Biaya Overhead & 372.799 .193 & 7.608 .147 & 380.407 .340 & 0 \\
\hline Jumlah & 1.451.752.400 & 29.627.600 & 1.481.380.000 & $\mathbf{0}$ \\
\hline
\end{tabular}

Sumber Data : CV Raffi Jaya Perkasa,2020 (diolah)

Taksiran Laba yang Wajar Berdasarkan Metode Kontrak Selesai dan Metode Persentase Penyelesaian

Hasl perbandingan biaya proyek dengan menggunakan metode kontrak selesai dan Metode persentase penyelesaian, maka taksiran laba atas pelaksanaan proyek Peningkatan Jalan Desa Sumber Agung menuju Kelurahan Keluang Kecamatan Keluang Tahun Anggaran 2019 dapat disajikan sebagai berikut :

Tabel 2

Taksiran Laba berdasarkan Metode Pengerjaan Proyek Konstruksi Peningkatan Jalan Desa Sumber Agung menuju Kelurahan Keluang Kecamatan Keluang CV Raffi Jaya Perkasa

Tahun Anggaran 2019

\begin{tabular}{|c|c|r|r|r||}
\hline \multirow{2}{*}{ Keterangan } & \multicolumn{2}{|c|}{ Metode Kontrak Selesai } & \multicolumn{2}{c|}{ Metode Persentase Penyelesaian } \\
\cline { 2 - 5 } & \multicolumn{2}{|c|}{ Tahun Anggaran } & \multicolumn{2}{c|}{ Tahun Anggaran } \\
\cline { 2 - 5 } & \multicolumn{1}{|c|}{$\mathbf{2 0 1 9}$} & $\mathbf{2 0 2 0}$ & $\mathbf{2 0 1 9}$ & \multicolumn{1}{c|}{$\mathbf{2 0 2 0}$} \\
\hline Pendapatan Proyek & 1.481 .380 .000 & 0 & 1.451 .752 .400 & 29.627 .600 \\
Biaya proyek & 1.390 .275 .130 & 0 & 1.364 .647 .256 & 27.849 .944 \\
\hline \hline Taksiran Laba & $\mathbf{9 1 . 1 0 4 . 8 7 0}$ & $\mathbf{0}$ & $\mathbf{8 7 . 1 0 5 . 1 4 4}$ & $\mathbf{1 . 7 7 7 . 6 5 6}$ \\
\hline
\end{tabular}

Sumber Data : CV Raffi Jaya Perkasa,2020 (diolah) 
Berdasarkan tabel diatas diketahui bahwa pada metode kontrak selesai semua pendapatan maupun biaya diakui pada periode tahun 2019 meskipun pada saat itu pekerjaan belum selesai $100 \%$ dimana kekurangan pekerjaan phisik itu akan dilanjutkan pada periode tahun 2020, sehingga laba yang diperoleh oleh CV Raffi Jaya Perkasa untuk proyek pekerjaan Peningkatan Jalan Desa Sumber Agung menuju Kelurahan Keluang Kecamatan Keluang tahun 2019 adalah sebesar Rp 91.104.870 dan tahun 2020 sebesar Rp. 0,00.

Sedangkan pada metode persentase penyelesaian laba yang diperoleh oleh CV Raffi Jaya Perkasa untuk proyek pekerjaan Peningkatan Jalan Desa Sumber Agung menuju Kelurahan Keluang Kecamatan Keluang tahun 2019 adalah sebesar Rp. 87.105.144 dan tahun 2020 sebesar Rp. 1.777.656. Perbedaan ini akibat tingkat persentase penyelesaian selama tahun 2019 maka pendapatan hanya diakui $98 \%$ dan tahun 2020 pendapatan diakui sebesar $2 \%$

Berdasarkan Pada hasil perhitungan diatas menunjukkan bahwa CV Raffi Jaya Perkasa dalam menghitung biaya proyek dan taksiran laba menggunakan metode kontrak selesai dalam pengerjaan proyek Peningkatan Jalan Desa Sumber Agung menuju Kelurahan Keluang Kecamatan Keluang tahun 2019. dimana pengerjaan proyek tersebut dianggap telah selesai 100\%, padahal kenyataanya proyek tersebut masih belum selesai atau progress pembangunan baru $98 \%$ tahun 2019 dan tersisa tahun 2020 sebesar 2\%. Alasan dianggap telah selesai 100\% pada tahun 2019 karena adanya kesepakatan antara pihak pemberi kerja dengan pihak kontraktor bahwa kekurangan phisik proyek akan diselesaikan seepatnya. Kekurangan phisik proyek ini biasanya tinggal pembersihan dan pekerjaan merapikan hasil pekerjaan saja.

Metode kontrak selesai adalah metode pengakuan pendapatan dimana perusahaan tidak mengakui pendapatan dan keuntungan sampai kontrak selesai. Metode ini biasa terjadi dalam kontrak jangka pendek seperti asa kontruksi, yang seringkali menghadapi ketidakpastian terkait dengan panggalan dana. Selanjutnya, perusahaan akan menunda kewajiban pajak mereka untuk periode mendatang sampai kontrak selesai. 
Metode kontrak selesai ini digunakan jika metode persentase penyelesaian tidak dapat di pakai lagi dan jika hasil kontrak kontruksi dapat di estimasi secara andal, maka entitas harus mengakui pendapatan kontrak dan biaya. Kontrak yang berhubungan dengan kontruksi masing-masing sebagai pendapatan dan beban yang di sesuaikan dengan tingkat penyelesaian aktivitas kontrak pada akhir priode pelaporan.

Berdasarkan hasil wawancara penulis dengan direktur perusahaan kontrak yang terjadi pada tahun 2019 dan 2020 masih bisa menggunakan metode persentase penyelesaian, karena pendapatan dan biaya terkait peroyek dapat di ukur ( di estimasi) oleh perusahaan bersama-sama pihak pemberi kerja. Sehingga dapat disimpulkan bahwa perusahaan belum menerapkan pengakuan pendapatan SAK ETAP Bab 20 yaitu pendapatan jasa konstruksi hanya diakui dengan menggunakan metode persentase penyelesaian, karena menggambarkan biaya hak perusahaan.

\section{SIMPULAN}

Berdasarkan hasil perhitungan dan analisis yang dilakukan dapat disimpulkan bahwa CV. Raffi Jaya Perkasa dalam menghitung biaya proyek belum sesuai dengan yang dituangkan dalan Standar Akuntansi Keuangan Entitas Tanpa Akuntabilitas Publik (SAK ETAP), khusunya proyek Peningkatan Jalan Desa Sumber Agung menuju Kelurahan Keluang Kecamatan Keluang Tahun Anggaran 2019 menggunakan metode kontrak selesai. ini mempunyai beberapa kelemahan, dimana tidak dapat menggambarkan kinerja sesungguhnya pada periode berjalan ketika masa kontraknya melampaui jangka waktu satu periode akuntansi atau jika masa kontrak selesai pada periode yang berbeda dan laba kotor hanya di akui pada saat kontrak di selesaikan dan di serahkan. Dengan demikian akan terjadi ketidaktepatan dalam penyajian pendapatan dan laba sepanjang periode akuntansi ketika masa kontrak belum selesai dan pekerjaanya belum di serahkan.

Untuk proyek yang akan datang perusahaan konstruksi sebaiknya menggunakan metode persentase penyelesaian sebagaimana dijelaskan dalam Standar Akunatnsi Keuangan Entitas Tanpa Akuntabilitas Publik (SAK ETAP), sehingga perusahaan akan mengakui pendapatan dan biaya sesuai dengan kemajuan 
perusahaan dalam menyelesaikan proyek dan tidak menangguhkan pengakuan unsur-unsur ini sampai kontrak diselesaikan. Jumlah Pendapatan akan diakui didasarkan pada ukuran tertentu dari kemajuan penyelesaian, sehingga laba yang dihasilkan lebih wajar dan dapat di hitung secara akurat setiap akhir periode (Smith dan Skousen 1987:230).

\section{DAFTAR PUSTAKA}

Diana Anastasia dan Setiawati Lilis. 2017. Akuntansi Keuangan Menengah Berbasis Standar Akuntansi Keuangan Terbaru. Yogyakarta : Andi.

Farida Nur Wanti, dkk, 2017. Perlakuan Akuntansi Pendapatan Jasa Outsourcing. (online). (http://eprints.jeb.polinela.ac.id/87/, di akses 15 maret 2020)

Ikatan Akuntansi Indonesia. 2016. Standar Akuntansi Keuangan Entitas Tanpa Akuntanbilitas Publik. Jakarta..

Smith, Skousen.1987. Akuntansi Intermediate. Jakarta : Erlangga

Stice dan Skousen.2011. Intermediate Accounting, Jakarta : Salemba Empat

Martani, Dwi dkk.2016. Akuntansi Keuangan Menengah. Jakarta: Salemba Empat.

Martani, Dwi dkk. 2017. Akuntansi Keuangan Menengah. Jakarta: Salemba Empat.

Sugiyono. 2019. Metode Penelitian Kuantitatif Kualitatif. Bandung: Alfabeta

Sugiyono. 2018. Metode Penelitian Kuantitatif, Kualitatif, dan R\&D. Bandung:

Alafabeta.

Sanusi, Anwar. 2012. Metodelogi Penelitian Bisnis. Jakarta: Salemba Empat 